Browne was fully justifed in his conclusions. In the Cambridge deposit we have two distinct faunas ; one, as shown by per-centages, related to the Chalk Marl, the other to the Upper Gault; two conditions of mineralization; evidence of erosion in the irregular junction of the two beds, in the waterworn condition of many of the nodules, in the fact that they had Plicatula. Polyzoa, etc. attached; the nodules also could be detected in the Ganlt, not only in the particular seam which had been described, but at intervals throughout the mass ; also erratics of some size occurred in the phosphate bed. These facts, he thought, proved the existence of a break. He thought that associated bones were rarer than $\mathrm{Mr}$. Seeley described them to be. It appeared to him that some of the speakers had forgotten that the question of the origin of the nodules had already been brought before the Society by Mr. Sollas and Mr. Fisher, who have shown very many of them to be phosphatized sponges.

Mr. Whitaker, from his experience in mapping the Geology of the Cambridge district, came to the conclusion that the bed is really the base of the Chalk Marl, there being a regular passage up into the latter. He questioned whether the Upper Greensand is a separate formation.

Mr. Hawkins Johnson said that the microscopical structure of the phosphatic nodules is identical with that of septaria from the London Clay, with that of the Clay-ironstone nodules of Yorkshire, and with that of some septaria from the Kimmeridge Clay. Moderately thin sections subjected to the action of dilute acid (even acetic acid), and examined while moist, show a structure like that of sponge.

The President remarked that the difference between Mr. Jukes-Browne and Mr. Seeley appeared to be on a question of fact. He remarked upon the difficulty of distinguishing between the Chalk and the Upper Greensand.

The Author, in reply, said that he was only concerned with the question of where the coprolites had come from, and not that of how they originated; he had not therefore touched upon the formation of phosphatic nodules. He thought Mr. Seeley had admitted some of the most important points of his paper, viz. the eroded surface of the Gault, the confluence of the Cambridge nodule-bed with that of the Gault, and the consequent derivation of many of its fossils. He must, however, maintain that there was a complete passage between the Greensand and the Marl above, and no trace of a second line of erosion, as Mr. Seeley appeared to think. With regard to the vertebrate remains, those preserved in dark phosphate were always worn and rolled, while the associated bones Mr. Seeley spoke of were light in colour, and undoubtedly belonged to the formation itself, i.e. to the base of the Chalk Marl. Lastly, the lists and per-centages contained in the paper would show whether or not there was a preponderance of Gault forms in the deposit, and the author was quite prepared to abide by observed facts and palisontological results.

\title{
CORIFSPONDEINCF.
}

\section{ON THE CRETACEOUS APORRHAÏDAF.}

Srr,-In the February Number, your contributor, Mr. J. Starkie Gardner, writing on Aporrhaïs retusa, Sow., says, "I cannot find the type or any specimen from Blackdown, and there is a doubt whether the same species is intended." It is curious that he should apparently not have read page 239 of Fitton's memoir, where it is stated that his types belonged to the Bristol Institution, and are "now in the Museum of that establishment." (See also Proc. Bristol Naturaliste' Soc., vii. pt. 2, p. 41.) In the Catalogue of Blackdown Fossils, pp. 239-242, Fitton is very careful to indicate against each species the collection in which the specimens may be found. Your contributor also writes, "Should the Blackdown form prove distinct, Deshayes's name of bicarinata must be adopted for it." We should 
claim priority for the Blackdown type; and in case of non-identity, it is the Gault form rather to which the French author's name may be apportioned. However, I have little doubt but that they are one and the same species. The single specimen, imperfect as to the digits, from which J. Sowerby drew up his description, seems to me to agree precisely with the Folkestone forms, except that the keels are a little less pronounced; but this is evidently due to the somewhat toned-down state of the specimen; there are seven to eight threads above the keel, and four between the keels, of which the two central are a little stronger than the remaining two. The surface, instead of being "particularly smooth," as Sowerby says, I should deseribe as showing traces of oblique cross lines, which have become very obscure through abrasion. I regret that I am unable to compare it with the foreign descriptions, but the Museum is quite without the necessary books.

Bristor Museum, February 18th, 1875.

E. B. Tawney.

\section{DEEP BORING IN PRUSSIA.}

SrR,-The experimental boring at Sperenberg having revealed the existence of a deposit of rock-salt, greatly exceeding that of any previously known, I send you some further details, for which I am again indebted to Professor A. von Koenen, of Marburg.

The boring was begun in gypsum, probably belonging to the Muschelkalk. As the boring proceeded, the gypsum was found to become gradually mixed with Anhydrite, and then to pass into pure Anhydrite.

Still lower, a little rock-salt was met with; and afterwards at 88.8 metres (291 English feet) pure rock-salt, in which the boring continued down to 1271.63 metres (4171 English feet); no other rocks besides gypsum and salt having been met with.

Twa other borings, at some distance from the first, have reached the rock-salt at 120.6 and 115.8 metres respectively, or at $395 \frac{1}{3}$ and 380 English feet.

Prof. von Koenen recommends English geologists, who take an interest in the subject of the increase of the Earth's temperature in proportion to depth, to consult the papers of Obergrath Dunker in that volume of the "Zeitschrift für das Berg- Hütten- und Salinen-Wisen 'in dem Preussischen Staate," which contains an account of the boring, viz. vol. xx. (1872).

The reduction of Prussian into English feet being incorrect in my former letter, I avail myself of this opportunity of rectifying the mistake: $85,100,363 \frac{1}{2}, 956,3095$, and 4051.6 Prussian feet are equal to $87 \frac{1}{2}, 103,374,983 \frac{3}{4}, 3184 \frac{3}{4}$, and $4172 \frac{1}{3}$ English feet respectively.

The average cost of sinking, therefore, amounted to about $£ 2.18 .9 d$. per foot English.

28, J JRMYN STREET, February, $187 j$.

H. W. BRIsTaw. 